\title{
Firm Level Strategy, Organization Culture and Performance of Food and Beverage Manufacturing Firms in Kenya
}

\author{
Zachary B. Awino ${ }^{1}$, Dominic C. Muteshi ${ }^{1}$, Reginah K. Kitiabi ${ }^{1} \&$ Ganesh P. Pokhariyal ${ }^{1}$ \\ ${ }^{1}$ University of Nairobi, Kenya \\ Correspondence: Zachary B. Awino, University of Nairobi, Kenya. E-mail: zb.awino@gmail.com
}

Received: September 4, 2017

Accepted: June 10, 2018

Online Published: June 30, 2018

doi:10.5539/ijbm.v13n8p224

URL: https://doi.org/10.5539/ijbm.v13n8p224

\begin{abstract}
The study tested the impact of organization culture on the on the relationship between firm-level strategy and performance of food and beverage manufacturing firms in Kenya. The opinion of the CEO/MDs from 125 firms in this sector was sought by application of a structured questionnaire; the collected data was analysed using hierarchical regression analysis. The paper stated hypothesis that organizational culture has a significant effect on the relationship between firm-level strategy and performance. The results supported the hypothesis. Therefore, firm development of strong organization culture to support firm-level strategy for higher performance is paramount. These findings will contribute to government policy formulation for sector's expansion and competitiveness and management drives in building a positive organization culture to support firm-level strategy for improved performance.
\end{abstract}

Key Words: firm-level strategy, organization culture, and firm performance

\section{Introduction}

Literature on strategic management extensively concedes that organizational culture is a factor which is critical in explaining how firms work and develop construct strategies for making them more productive (Prajogo \& Sohal, 2001). Therefore, organizations with unique and dynamic culture that is focused on supporting innovation and creativity will actively influence employees to take initiatives in formulating and implementing strategies with the intent of gaining high performance and sustainable competitive advantage (Cristian-Liviu, 2013). Studies on the direct and indirect connections between firm-level strategy and performance have overlooked the impact of organizational culture and yet a strong culture could be the only separating difference between two fierce competitors (Denison, 2000; Navdeep, 2010).

Empirical evidence demonstrates existence of considerable investigations on the linkages among strong culture and high level performance and poor culture and low performance. However, the situations where a firm with a strong culture could experience poor performance and a firm with a weak culture posting higher performance is not properly grounded in literature (Jochisen \& Naipier, 2013). Most leaders agree that culture is the vital factor in performance, but can't define it, measure it or change it (Prajogo \& Sohal, 2001). As a consequence, the few ventures that get the culture accurate appear mysterious and managers who attempt to duplicate their success usually end up frustrated and cynical. Performance may be affected by the existing organizational culture as firm's with a positive culture, with similar values and behaviour codes help in the accomplishment of their objectives and vision (Tsai, 2011). Thus, the management food and beverage manufacturing firms (FBMF) have to undertake various configurations of strategy and resources to register different outcomes of performance (Aosa, Bagire \& Awino, 2012). This study postulates that there is a significant relationship between firm-level strategy, organizational culture and performance.

The construct of culture has remained elucidated differently in studies on firm management. For instance, Mehta and Krishnan (2004) defined organizational culture as the shared and learned customs, traditions, attitudes, values, norms, practices and beliefs that shape and influence perception and behaviourism of a cluster of individuals engaged in an organization. Hofstede and Hofstede (2005) defined culture as the combined programming of the mind which differentiates the affiliates of one society or class of people from another. Culture is developed from ethnic, religious, racial and educational backgrounds and there is no compromise found in literature on one definition of the construct (Barney, 1986). Therefore a flexible culture will ensure less resistance from staff on the new corporate strategies for higher productivity. 
Hofstede and Hofstede (2005) developed a model for cross-cultural communication, which details the inspiration of a group's culture on the values of its members, and how these values influence their behaviour. However, Denison (2000) classified organizational culture to involve four dominant cultural traits of involvement, consistency; adaptability, and mission. While Mehta and Krishnan (2004) grouped culture in a spectrum of weak to strong and discovered out that performing firms apparently have productive cultures. The culture dimensions affect a firm in that as the cultural factors change, human perceptions, customer behaviour and thus demand for different products are affected. Studies have revealed that there exists a critical link between beliefs and traditions and these manifestations are at the core of managing cognitive processes for better performance (Hofstede, Hofstede, \& Minkov, 2010). A firm with great organizational culture possesses corresponding good values and codes of behaviour for its staff, and this aids them to attain their firm objectives and missions (Tsai, 2011). Thus the bearing of corporate cultural change is felt in the changing demands, tastes and preferences of consumers. Therefore, culture denotes to a group of beliefs and values that characterize a given society. Culture therefore, influences the way personnel act in the workstation and can affect their motivation in executing firm-level strategy for performance improvement.

Dunn (2012) argued that many firms understand the advantages of a noticeable culture, but may not necessarily view it as a strategy. There is a consensus that companies making an effort to introduce a progressive culture which builds free interaction among members and motivates employees to question fundamental beliefs, will develop a conducive working environment (Lopez, Peon, \& Ordas, 2004). Businesses have unique histories over the route in which particular cultures and norms develop. This customs, norms, attitudes, and traditions may be melded judiciously to form a synergistic work culture where individuals work cooperatively in line with firm goals as employees feel motivated and satisfied (Nguyen, Mujtaba, \& Pham, 2013). This argument stresses the essence of culture in performance improvement and strategy operationalization.

It is recognized to be very complicated to measure a typology of organizational culture. However, Cameron and Quinn (1999) model of Competing Values Framework (CVF) has been used in previous empirical studies (Ahmadi, Salamzadeh, Daraei, \& Akbari, 2012) with reliable results. The Cameron and Quinn's CVF model uses two landscapes to group culture into four types as hierarchy, clan, market, and advocacy. The research though recognizing the existence of other typologies of culture, the study used CVF model as it is the most spacious and comprehensive model in measuring organizational culture (Bill \& Kristine, 2007; Ahmadi et al., 2012). Research has established that culture of productivity is the main essential principle of the theory of firm performance. A healthy culture may be the only separating difference between two fierce competitors (Navdeep, 2010). Hence, this paper pursued to establish culture's effect on firm-level strategy and performance relations.

Literature scrutiny on organizational culture reports that for firms to successfully implement their strategies for organizational performance implications, organization culture is a critical tool but empirical work carried out to investigate this relationship is still limited (Reichers \& Schneider, 1990). Further, the effect of organizational culture on the firm performance is reported directly or indirectly significant (Denison, 1990). Based on the above background, the specific objective of this study was to explore the influence of organizational culture on the relationship between firm-level strategy and performance of FBMFs in Kenya.

Resource-based view (RBV) theory will immensely benefit from the arguments on firm-level strategy, organizational culture and performance. The results will assist the Kenyan government in formulating policies for the sector meant to improve its performance. The management will also benefit in building a progressive culture for their firms. This paper is organized into five sections. Division two placed interest in empirical studies which formed the conceptualization and contextualization of the study. Research methodology adopted in the study; the design, population, respondents and analytical tools are illustrated in the third division. Section four concentrates on the findings of the analysis and interpretations. Section five covers conclusion, recommendations, constraints and areas for additional studies.

\section{Literature Review}

The theoretical foundation of this paper is founded on reviewed empirical studies. The casual correlations among firm-level strategy, organizational culture and performance have been broadly identified. The study was anchored on Resource-Based View (RBV) Theory (Wernerfelt, 1984). The theory is prevalent in management science. RBV advocate that the sustainability of a firm's success is subject to creation, development, and enactment of a given company's unique strategies and competencies (Zollo \& Winter, 2002). RBV as a source for organizational performance lies largely in the utilization of a package of cherished physical or intangible resources at the firm's disposal (Wernerfelt, 1984; Penrose, 1995). RBV stresses the prominence of analysing the capabilities belonging to the firm, how it uses them, the characteristics they have, or the new competencies 
developed in the enterprise from the existing interactions and complementary (Grant, 1996; Barney, 2002). Based on the conceptual framework, this study analyses the stimulus of culture on the relationship between firm-level strategy and performance.

Central to this theory is that the main task of an RBV approach to firm-level strategy making is on exploitation of profits over a period (Barney, 1991). Firm attainment of sustainable competitive success results and performance only occurs from strategic assets. Strategic assets are firm resources which are valuable, rare, imperfectly imitable and non-substitutable (VRIN) as a basis for competitive advantage (Barney, 1991). RBV incorporates the typical strategy acumens about firm's idiosyncratic capabilities and heterogeneous resources (Mahoney \& Pandian, 1992). While elaborating resource-based view Barney (1986), emphasized on the significance and role of firm's unique resources and distinct competencies in establishing the size of firm's capacity to manage innovation.

The underlying assumptions of RBV are that resources are not homogeneously spread across firms and that this heterogeneity can be sustained over time. This explains how firms can earn super profits in equilibrium and as such, it is primarily a static view (Barney, 2001a \& 2001b). The long-term performance and sustainable competitiveness of a firm depend on its endowment of resources that are durable, hard to imitate or substitute and that differentiate it from its rivals (Grant, 2003; Rothaermel, 2008). Therefore, a firm that effectively manages knowledge about its customers, technologies, products to those of competitors posts superior performance. Dadzie, Winston and Dadzie (2012) argued that companies with a principally teamwork and competitive cultures are more probable to be directly connected with performance. In addition, firms with innovative or structured cultures are more possibly to be indirectly linked with performance conditioned on their configuration with differentiation strategy or cost leadership strategy.

Firm performance is enhanced when resources are reconfigured, recombined and reallocated according to the requirements (Hamel \& Prahalad, 1990). While appreciating the arguments of (Porter, 2008; Nguyen et al., 2013) who postulated that having operational efficiency alone cannot be argued to constitute a tactic as strategy works in different ways by performing at a cost-effective and profitable fashion. The complexity of the environment has forced firms to include in their strategic plans other dimensions of performance beyond monetary, marketplace and technological considerations (Hamel \& Prahalad, 1990), while the studies focused on the resources theory. Ray, Barney \& Muhanna (2004) argued that firms must transform their capabilities efficiently and effectively into a business process. Thus, the realisation of a firm objectives hinges on the resources it possesses (Kuhn \& Grunig, 2000). The study supports the RBC paradigm of Resources - Conduct - Performance (R-C-P).

Gupta (2011) argued that there is a significant dissimilarities in the strategy and culture of firms belonging to different industries. Companies characterized with a reassuring and vibrant organizational culture have a high prospective of a strategy invention and implementation. Companies in the matching commerce can have similar corporate strategies and capabilities but vary in performance (Parnell, Long \& Lester, 2015). This could be associated with cultural factors which include the beliefs, traditions, values, attitudes, lifestyle, and aesthetics related to the company by the external environment. Cultural metamorphoses manifest in numerous ways values, practices, rituals, symbols, and heroes (Hofstede \& Hofstede, 2005). Hence, successes of adopted firm strategies for improved performance are moderated by healthy organizational culture. Furthermore, culture is unique to every firm and industry. Subsequently, Schein (1995) argued that culture is a vital concept that can limit or enable firm strategy. Further, Bill and Kristine (2007) identified that comprehending the type of enterprise as the foremost initiator of culture.

Organizations applying prospector strategy are high on adhocracy culture while those with both clan and adhocracy cultures are those firms that use analyser strategy. Corporations with reactor and defender strategies are usually great on clan and hierarchical respectively (Gupta, 2011). Kariuki (2017) argued that culture of a company has a significant affinity to return on assets. Consequently, culture can be implied as an essential alter of a casual effect of corporate strategy and performance. Culture is seen as the soft side of management, and is the hardest because it deals with attitudes and behaviours which all look a bit vague owed to its unpredictability but is critical to the company. Empirical confirmation shows that each company faces a different reality in the marketplace depending on its goods, competitors, consumers, technologies and government regulatory policies. In summary, the surrounding in which a concern functions governs strategies to be adopted. No organization adopts to a unitary type of culture and complex firms may have sub-cultures that overlap and disagree with each other (Cacciattolo, 2014). Thus, culture is learned, and it is imitated to one's social operating environment (Hofstede \& Hofstede, 2005).

Organizational culture, therefore, consists of patterns of mannerisms that are learned, interrelated and shared; 
and corporate culture is exceptional and defines the latitude of an explicit class of people. Despite claims of moderating linkages, the culture-performance bond remains vague, and there is a need to improve on the arrangement of the concepts, methodology in studying the variables (Ahmadi et al., 2012). The highest number of managers agree that culture is a solemn factor for firm performance, but they cannot define it, quantify it or modify it (Tsai, 2011). As a consequence, the few companies that get the right cultural manifestations reduces any external attempts to reproduce their accomplishments ordinarily culminates to unfulfilled and pessimistic outcomes.

A mass of culture typologies is available in the literature. Cameron and Quinn (1999) model are one of the prominently recognized models created based on empirical data. The two scholars suggested a model for judging an organizational culture by taking two dimensions, stability/control versus flexibility/discretion and internal focus versus external focus. The framework describes four forms of culture: hierarchy, clan, market, and adhocracy (Cameron \& Quinn, 1999). Organizational culture was operationalized using Cameron and Quinn typology in Figure 1.

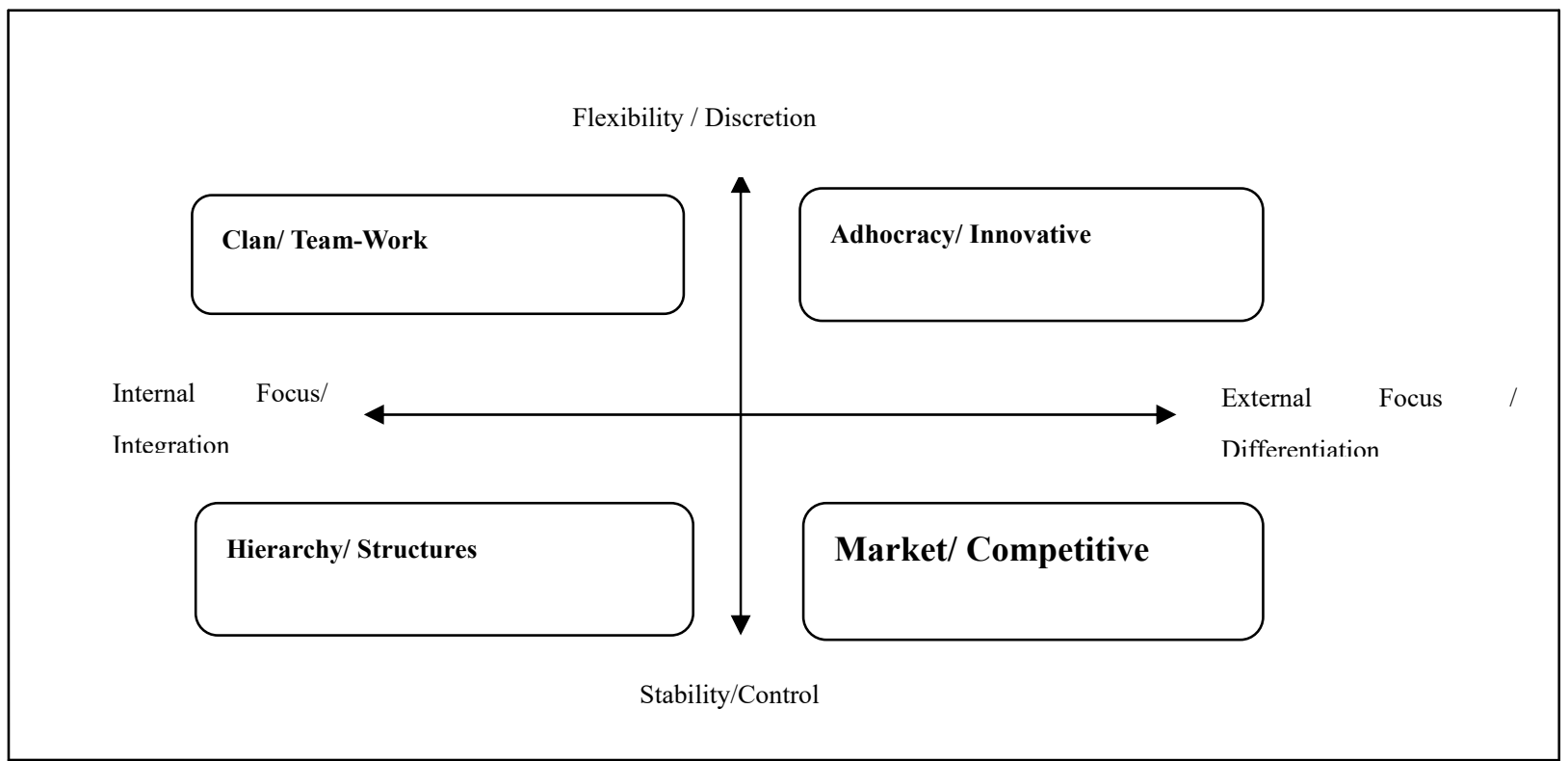

Figure 1. Organizational culture typology model

Adhocracy culture emphasizes flexibility, change, and it's externally oriented. The crucial tenets of adhocracy are innovation, entrepreneurship, and risk-taking. The second class of culture is the clan which stresses on flexibility but internally focused. Clan culture is branded with discretion, solid team-work, employee involvement and corporate commitment to staff. The third category of culture is a market culture which discourses on regulation, solidity and is outwardly oriented. The core principles of a firm with this culture are objective realization, uniformity, and competitiveness. Lastly, hierarchy culture is control oriented but ponders on the internal environment. Its fundamental values are productivity and close adherence to policies and regulations (Ahmadi et al., 2012).

Literature review suggests that managing cognitive procedures for improvement of performance entails that firms attend to characteristics by which people make logic of everything they do relative to a more significant set of fundamental norms (Fiol, 1991). Firm's with positive culture builds goodwill which is an essential component of firm value (Pruzen, 2001). Internationally, it is proven that successful firms ostensibly have resilient cultures which are only valuable if they exhibit the adaptive and learning qualities that are rare to the cultures of other firms (Mehta \& Krishnan, 2004; Siew \& Kelvin, 2004).

According to Aluko (2013), culture is significantly associated with organizational performance. Yesil and Keya (2013) established that culture has no relationship on company's financial performance. These studies focused on organizational culture as an independent variable on performance but overlooked its moderating impact on firm-level strategy and performance relationships. The firm's innovation process is guided by a clear firm-level strategy, which provides direction towards specific capabilities and helps the company to concentrate on the drives of the whole firm to the common goal (Oke, 2007). However, Rothaermel (2008) and Awino (2011) posit that the autonomous consequence of capabilities, strategy and their operationalization on firm's performance is 
insignificant when equated to the joint effect of the same variables.

Pearce, Robinson and Mital (2012) contend that the growing of firm-specific capabilities is vital to strategy implementation for organizational performance and survival. Norton (1998) argued that resource allocation ought to propose a proof of strategic significance. If a firm differentiates and binds resources, that commitment suggests a comparative weight on performance. It is the absolute prominence of assets that triggers the strategic significance. A study conducted by Murgor (2014) on manufacturing companies, established that external surrounding, capabilities and strategic reactions singularly contributed to firm performance more than the combined inspiration of the same variables. Hence, firms should respond to legitimate forces, openings and threats individually to build appropriate capabilities (Johannesson \& Palona, 2010). It follows that, due to existing contradictions in literature on constructs that inform performance, the study incorporates culture as a new variable to test if it will replicate the results.

Organizational culture is paramount because it gives consistency, order, chain of command, and sets internal mechanisms of internal interactions. It determines conditions for firm effectiveness, strategy operationalization and drives effective performance (Bill \& Kristine, 2007; Ahmadi et al., 2012). The pervasiveness of firm's culture dictates that management should value the underlying indicators of organization's culture and its effect on employee-connected variables like satisfaction, engagement, commitment, teamwork, strategy execution and performance (Lund, 2003). For firms to achieve high performance, they should configure existing resources within a dynamic surrounding through the establishment of a sound strategy with proper resources utilization (Barney \& Aiken, 2001; Aosa et al., 2012). However, these studies failed to consider the consequence of culture connections between firm-level strategy and performance.

Empirical studies postulate that managing cognitive processes for improved performance requires that firms attend to identities by which people make sense of what they do about a broader set of organizational norms (Fiol, 1991). Firm's with productive culture builds strong goodwill which is an essential component of firm value (Pruzen, 2001). Globally, successful firm's apparently have active cultures which are only valuable if they exhibit an adaptive, rare and learning qualities to those of competing firms (Mehta \& Krishnan, 2004; Siew \& Kelvin, 2004). According to Aluko (2013), culture is significantly associated with organizational performance. While Yesil and Keya (2013) established that culture has no relationship on firm's financial performance. A flexible culture concentrated on supporting strategic options will enthusiastically inspire employees to take initiatives in constructing and executing strategies with the resolve of gaining organizational culture competitive edge and performance (Gupta, 2011). However, these studies overlooked culture effect on firm-level strategy and performance relationships.

Fashioned from these limitations in scholarly works, the objective of this study was to determine the effect of organizational culture on the connections amongst firm-level strategy and performance of FBMF in Kenya. The paper hence aims to offer a solution to research question as to whether organizational culture affects firm-level strategy and performance connections that remains unclear in literature.

$\boldsymbol{H}_{01}$. Organizational culture has a significant effect on the relationship between firm-level strategy and performance of FBMFs in Kenya.

\section{Methods}

To explore the effect of organizational culture on the relationship between firm-level strategy and performance of FBMF, we analysed data from 125 large-scale firms that were active members by Kenya Association of Manufacturers (KAM) by 2016. We chose registered firms because they account for $80 \%$ of the gross population of the sector under study. A census sampling of the marked populace was justifiable due to the decline in total population. The study was for a two year period running from January 2016 - December 2017. In Kenya, FBMF is classified under the manufacturing sector which is an essential sector of the economy contributing about $10 \%$ of Gross Domestic Product (GDP) (KIPPRA, 2014).

Manufacturing sector employs nearly 300,000 people accounting for $13 \%$ of the Kenyan national employment. It is established that the industry's account of the GDP has been on decline trend from $13.9 \%$ in 2008 , to $11 \%$ in 2010 , to $9.6 \%$ in $2011,9.2 \%$ in 2012 . The sector's proportion to the wage employment has also steadily declined from $13.9 \%$ in 2008 to $12.8 \%$ in 2012 (KIPPRA, 2014). The decline in growth of this sector is attributed to a blend of factors, including high rising costs food ingredients, rising wage bills, increased establishment costs for new companies from COMESA nations and tightened bank loan requirements. The key respondents were the Chief Executive Officers/ Managing Directors of the FBMF. 125 representing a 70\% response rate filled and returned the structured questionnaire. 
The scholars analysed the data using hierarchical regression and the results presented using inferential and descriptive statistic. To test the hypothesis of this study, the results of the independent effect of the organizational culture on each performance indicator and followed by the combined effect of the responses then finally those of the composite indices of the two variables. Organizational culture dimensions (hierarchy, clan, market and adhocracy) were regressed on the relationship between firm level strategy dimensions and firm performance. The hierarchical regression model was $\mathrm{P}=\mathrm{f}$ (Firm Level Strategy + Organizational Culture): $\quad \mathbf{Y}=\beta \mathrm{o}_{3}+\beta_{1} \mathrm{X}_{1}+\beta_{3} \mathrm{X}_{1}$ $* X_{3}+\varepsilon_{3}$.

\section{Results}

The results of the combined moderating effects of organizational culture on the relationship between firm level strategies and organizational performance are presented in Table 1.

Table 1. Independent effect of firm-level strategy, organizational culture and performance

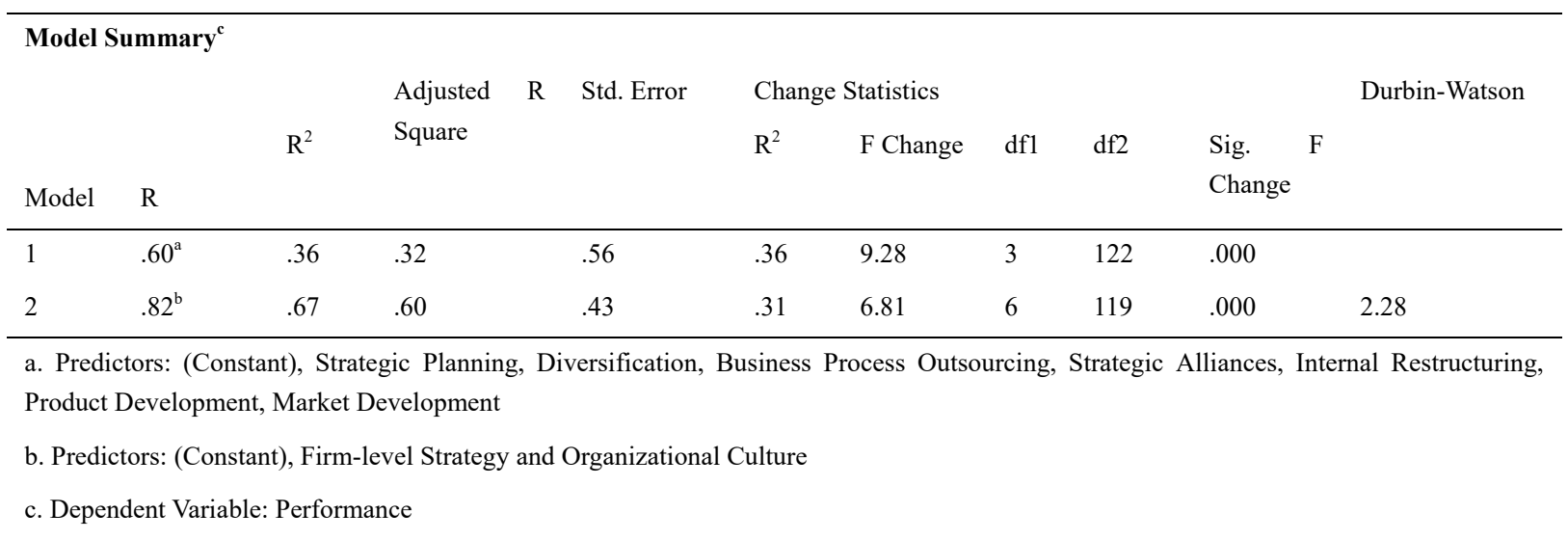

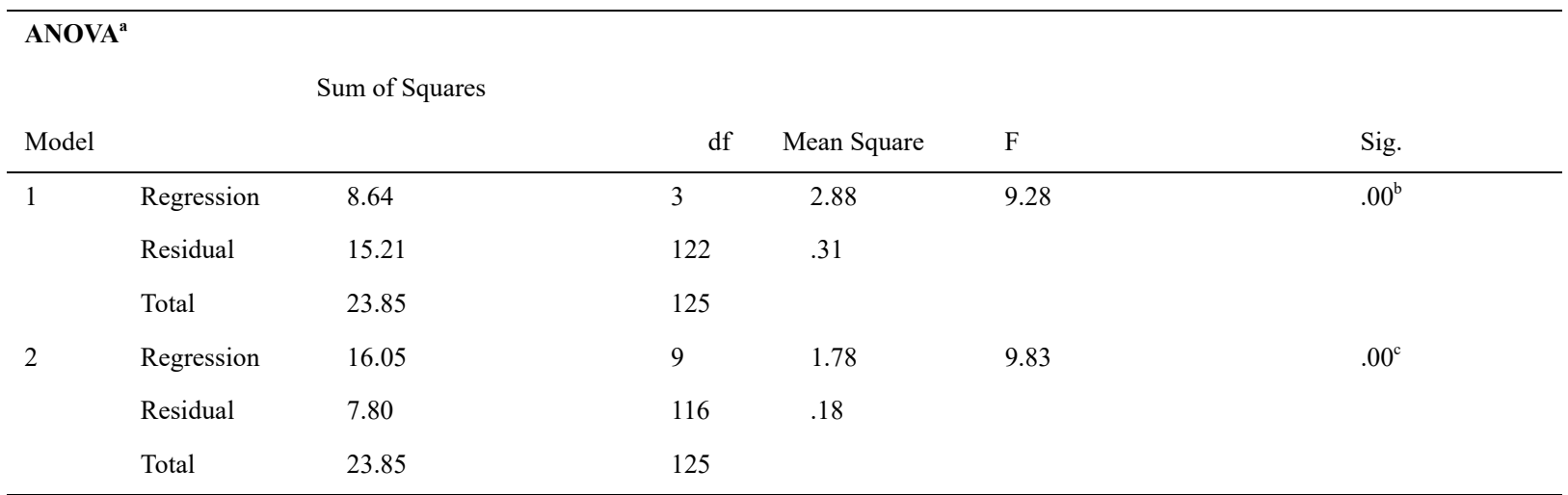

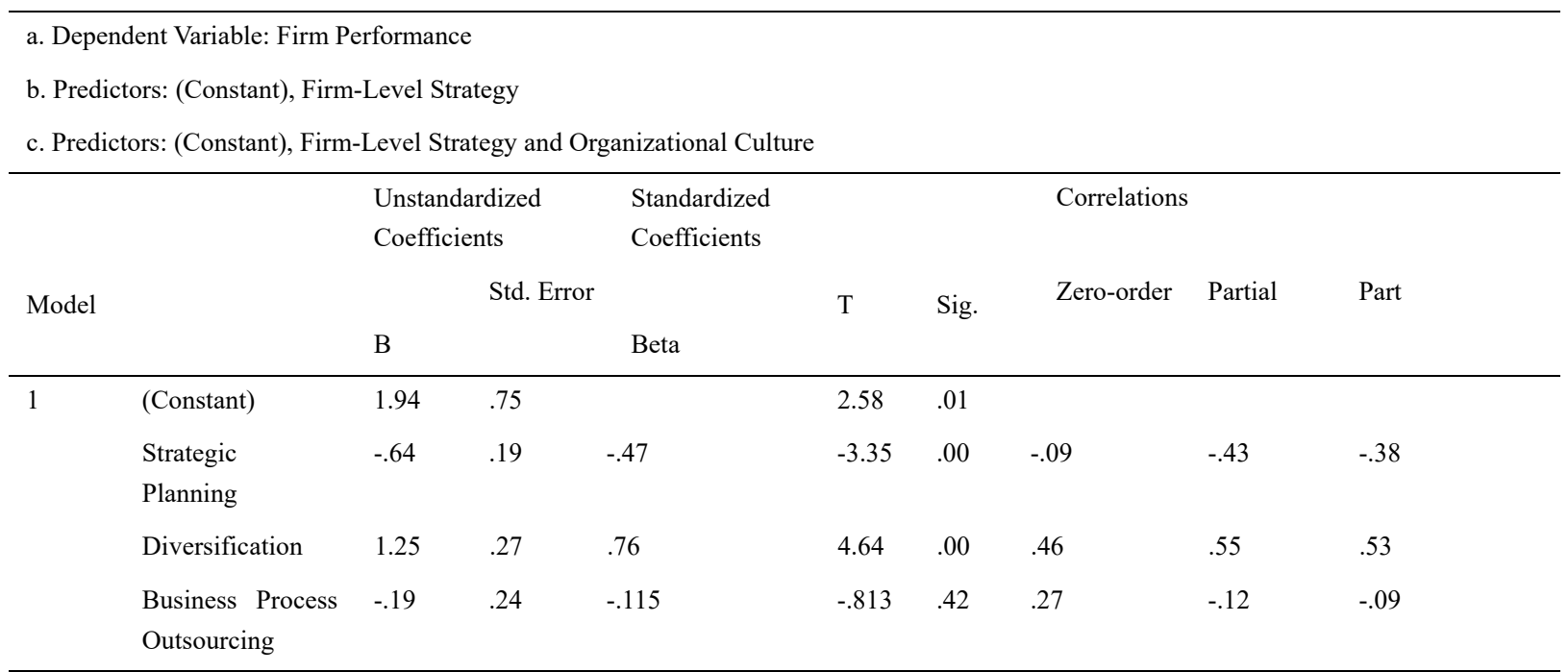




\begin{tabular}{|c|c|c|c|c|c|c|c|c|c|}
\hline & Strategic & 1.61 & .70 & & 2.30 & .03 & & & \\
\hline & Alliances & & & & & & & & \\
\hline & Internal & -.56 & .17 & -.404 & -3.35 & .00 & -.09 & -.46 & -.29 \\
\hline & Restructuring & & & & & & & & \\
\hline & Product & .55 & .29 & .28 & 1.90 & .06 & .37 & .26 & .23 \\
\hline & Development & & & & & & & & \\
\hline & Market & .55 & .24 & .34 & 2.32 & .03 & .38 & .33 & .25 \\
\hline & Development & & & & & & & & \\
\hline 2 & Constant & 1.11 & .23 & .67 & 4.79 & .00 & .46 & .59 & .42 \\
\hline & Strategic & -.43 & .21 & -.26 & -2.12 & .04 & .27 & -.31 & -.18 \\
\hline & Planning & & & & & & & & \\
\hline & Diversification & .37 & .09 & .47 & 3.92 & .00 & .54 & .51 & .34 \\
\hline & Business Process & .02 & .13 & .02 & .14 & .89 & .34 & .02 & .01 \\
\hline & Outsourcing & & & & & & & & \\
\hline & Strategic & .08 & .07 & .13 & 1.18 & .25 & .48 & .18 & .10 \\
\hline & Alliances & & & & & & & & \\
\hline & Internal & -.56 & .17 & -.40 & -3.35 & .00 & -.09 & -.46 & -.29 \\
\hline & Restructuring & & & & & & & & \\
\hline & Product & .24 & .10 & .33 & 2.40 & .02 & .27 & .34 & .21 \\
\hline & Development & & & & & & & & \\
\hline & Market & .55 & .24 & .34 & 2.32 & .03 & .38 & .33 & .25 \\
\hline & Development & & & & & & & & \\
\hline & Organizational & -.30 & .12 & -.35 & -2.47 & .02 & .08 & -.35 & -.22 \\
\hline & Culture & & & & & & & & \\
\hline
\end{tabular}

a. Dependent Variable: Firm Performance.

The results of the analysis to establish the effect of firm-level strategy dimensions and organizational culture on performance are shown in Table 1. Results of the study showed a substantial relationship $(\mathrm{R}=.82)$. Firm-level strategy dimensions and organizational culture together explained $67 \%(\mathrm{R} 2=.67)$ of performance with the remaining $33 \%$ being elaborated by other variables. In sub model one, firm-level strategy alone describes $36 \%$ of the variation in performance. This therefore exhibits $35 \%$. The F value for the model was 9.83 at a p-value less than $0.05(\mathrm{p}<0.5)$, implying that the individual constructs had statistically significant effects on performance. The findings of the joint effect of organizational culture on firm-level strategy and performance are presented in Table 2.

Table 2. Combined effect of organizational culture on the relationship between firm-level strategy and performance

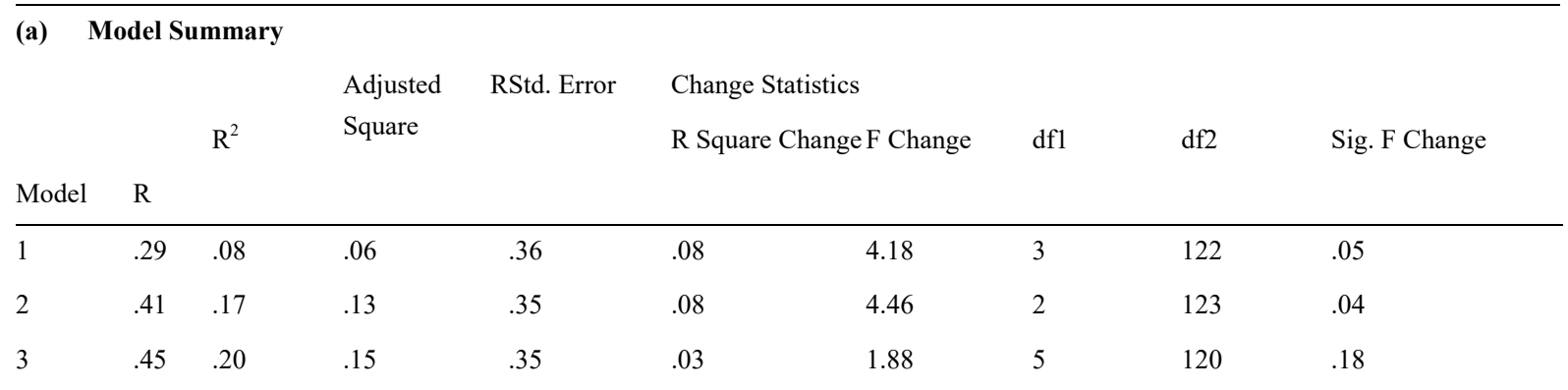

\section{(b) ANOVA}

\begin{tabular}{llllll} 
Model & Sum of Squares & df & Mean Square & F & Sig. \\
\hline 1 & Regression & .56 & 1 & .556 & 4.181 \\
\hline
\end{tabular}




\begin{tabular}{|c|c|c|c|c|c|c|}
\hline & Residual & 6.12 & 124 & .133 & & \\
\hline & Total & 6.68 & 125 & & & \\
\hline & Regression & 1.12 & 2 & .554 & 4.479 & .017 \\
\hline \multirow[t]{3}{*}{2} & Residual & 5.57 & 123 & .124 & & \\
\hline & Total & 6.68 & 125 & & & \\
\hline & Regression & 1.34 & 5 & .446 & 3.672 & .019 \\
\hline \multirow[t]{2}{*}{3} & Residual & 5.34 & 120 & .121 & & \\
\hline & Total & 6.68 & 125 & & & \\
\hline
\end{tabular}

\section{(c) Coefficients}

\begin{tabular}{|c|c|c|c|c|c|c|c|}
\hline \multirow{3}{*}{ Model } & \multicolumn{4}{|c|}{ Unstandardized Coefficients Standardized } & & \multicolumn{2}{|c|}{ Collinearity Statistics } \\
\hline & \multirow[b]{2}{*}{ B } & \multirow[b]{2}{*}{ Std. Error } & \multicolumn{3}{|c|}{ Coefficients } & \multirow[b]{2}{*}{ Tolerance } & \multirow[b]{2}{*}{ VIF } \\
\hline & & & Beta & $\mathrm{t}$ & Sig. & & \\
\hline (Constant) & 2.12 & .31 & & 7.78 & .01 & & \\
\hline${ }^{1}$ Firm-level strategy & .20 & .09 & .29 & $2.05^{*}$ & .00 & 1.00 & 1.00 \\
\hline Performance & 1.57 & .11 & .33 & $4.24^{*}$ & .05 & .98 & 1.02 \\
\hline (constant) & .23 & .32 & & $2.41^{*}$ & .02 & & \\
\hline${ }^{2}$ Firm-level strategy & .16 & .09 & .29 & $2.11^{*}$ & .00 & .98 & 1.023 \\
\hline Organizational culture & .13 & .11 & .38 & $4.22^{*}$ & .00 & .98 & 1.09 \\
\hline \multicolumn{8}{|c|}{ Firm-level strategy and } \\
\hline $\begin{array}{l}\text { 3organizational } \\
\text { interaction }\end{array}$ & e .08 & .07 & .20 & $1.37^{*}$ & .04 & .96 & 1.04 \\
\hline
\end{tabular}

a. Predictors: (Constant), Organizational Culture, Firm-Level Strategy.

b. Predictors: (Constant), Organizational Culture, Firm-Level Strategy, Interaction Term between Organizational Culture, Firm-Level Strategy.

c. Dependent Variable: Firm Performance.

In step two firm-level strategy was regressed on organizational culture. In step three the interaction term between firm-level strategy and organizational culture was introduced. The moderation effect is confirmed when the effect of interaction term is statistically significant. Regression results displayed in Table 2 show that the regression model was robust and thus fit for the analytical task for which it was intended $(\mathrm{F}=4.18, \mathrm{P}<0.05)$. Both $\mathrm{R}, \mathrm{R} 2$ and beta coefficient are significant $(\mathrm{R}=0.29, \mathrm{R} 2=0.08, \mathrm{~F}=4.18, \mathrm{P}<0.05)$ suggesting that regression model explains $8 \%$ of the variance in performance. Further, it is evident in model one in the table that for every unit change in firm-level strategy, there is a corresponding $29 \%$ change in performance $(\beta=0.29, \mathrm{t}=2.05, \mathrm{P}<0.05)$. In model two, the variance changes to $29 \%$ for firm-level strategy $(\beta=0.29, \mathrm{t}=2.11, \mathrm{P}<0.05)$ and $38 \%$ with respect to organizational culture $(\beta=0.38, \mathrm{t}=4.22, \mathrm{P}<0.05$. The findings from the test of hypothesis imply that organizational culture strengthens the effect of firm-level strategy on performance.

The interaction between organizational culture and firm-level strategy stimulated performance to support a moderation relationship. The results indicate that firm-level strategy and organizational culture have a significant influence on performance $(\mathrm{t}=-1.37, \mathrm{p}=<0.05)$. This implies that firm-level strategy depends on the organizational culture in determining the performance; thereby accepting the hypothesis, that organizational culture moderates the effect of firm-level strategy on performance. The overall regression equation for this model is $\mathrm{Y}=$ $-.4 .05-.55 \times 1-.509 \times 2-.79 \times 3+2.23 \times 4$; Based on the statistical test of the beta coefficient $(\mathrm{t}=7.69, \mathrm{p}<0.001)$, the independent variable firm size, the alternative hypothesis that the slope/ beta coefficient was equal to 0 (zero) was accepted. The beta coefficient/slope for the relationship between the TBQ ratio and the moderating variable organizational culture was .99 , invariably meaning that there is a direct relationship as signified by the positive coefficient.

\section{Conclusion}

The study is one of the few investigations that have empirically confirmed full moderation effect of 
organizational culture on firm-level strategy and organizational performance. The results imply that when firms develop healthy organizational culture, firm-level strategy seizes to guide firm performance. Consequently, the results confirm that organizational culture has a significant effect on firm-level strategy and performance relationships. The culture impact as demonstrated in the study are even with the RBV which holds that firm performance is actualized through utilization of resources at its disposal (Penrose, 1959).

The results in Table 1 for the test of the influence of firm-level strategy and organizational culture on the performance of FBMFs in Kenya was statistically significant and positive $(\mathrm{R} 2=0.52$; Std. Beta $=0.63$ $\mathrm{p}$-value $\leq 0.05$ ). Thus, the results led to the acceptance of the alternative hypothesis that organizational culture has a significant impact on firm-level strategy and organizational performance relationship. It shows that variation in organizational culture caused $47 \%$ of changes in independent and dependent variables. Therefore, management should foster a strong organizational culture for success in organizational performance.

The interaction R2 when adhocracy culture was introduced in the model of R2 $=0.42$; Std. Beta $=0.46 ; p$-value $\leq 0.05$ ) was the highest indicator of organization culture control on the relationship between firm-level strategy and organizational performance. These findings suggest that $37 \%$ of changes in firm-level strategy and performance resulted from innovations and creative cultures. The culture indicator with the lowest contribution on firm-level strategy and organizational performance was hierarchy culture whose R2 $=0.21$; Std. Beta $=0.42$; $p$-value $\leq 0.05$. These findings indicate that changes in organizational policies and structures only accounted for $16 \%$ changes in organizational performance. The results support previous studies of (Siew \& Kelvin, 2004; Fazil \& Alishahi, 2012; Aluko, 2013; Kariuki, 2017) who argued that firm strategy and strong culture has a substantial bearing on performance. However, the results contradicted the position of Yesil and Keya (2013), who argued that culture only impacts a variety of firm performance but not in all sectors.

The primary limitation of the study was in the research method. Cross-sectional design lacks the rigor to test connections between variables. The moderation of culture on firm-level strategy and performance; requires a longitudinal design as the evaluation of the constructs is more suitable if tested for a 5-10 year period. Even though, hierarchical regression analysis is a powerful analysis tool; the method is sensitive to the order in which the concepts are entered in the programmer. Future studies should consider using other analytical tools such as Tobin Q or multivariate analysis. The second constrains of the study was the choice of top management as the only respondents. Subsequently, the element of bias could not be overruled entirely. The viewpoint of other stakeholders like senior executives or unionize employees might have been ignored. Future inquiries should consider investigating the effect of different variables like national culture, corporate governance, and external environments inspirations on the connections among firm-level strategy and performance.

\section{References}

Ahmadi, S. A., Salamzadeh, Y., Daraei, M., \& Akbari, J. (2012). Relationship between organizational culture and strategy implementation: Typologies and Dimensions. Global Business \& Management Research: An International Journal, 4(4), 286-299.

Aluko, M. A. O. (2013). The impact of culture on firm performance in selected textile firms in Nigeria. Nomadic Journal of Africa studies, 12(2), 164-179.

Aosa, E., Bagire, V., \& Awino, Z. (2012). The interaction of personal factors, structure and performance in NGOs. DBA Africa Management Review, 2 (3), 25-41.

Awino, Z. B. (2011). Strategic management: An empirical investigation of selected strategy variables on firm performance: A study of supply chain management in large private manufacturing firms in Kenya. Prime Journals: Business Administration and Management (BAM), 1(1), 09-18.

Barney, J. B. (1986). Strategic factor markets: Expectation, luck and business strategy. Management Science, 32(10), 1231-1241. https://doi.org/10.1287/mnsc.32.10.1231

Barney, J. B. (1991). Firm resources and sustainable competitive advantage. Journal of Management, 1(17), 99-120. https://doi.org/10.1177/014920639101700108

Barney, J. B. (2001a \& 2001b). Resource based theories of competitive advantage. A ten year retrospective on the resource based view. Academy of Management Review, 27(6), 643-650. https://doi.org/10.1177/014920630102700602

Barney, J. B. (2002). Gaining and sustaining competitive advantage. Upper Saddle River, NJ: Prentice Hall.

Barney, J., \& Aiken, A. M. (2001). The resource-based view: Origins and implications. In M. A. Hitt, R. E. Freeman and J. R. Harrison (Eds.), Handbook of strategic management (pp. 124-188). Oxford, UK: 
Blackwell Publishers.

Bill, W. S., \& Kristine, S. (2007). Aligning culture, leadership and strategy. Management Forum Series, 2006-2007.

Cacciattolo, K. (2014). Understanding organizational cultures. European Scientific Journal, 2(1), 1-7.

Cameron, K., \& Quinn, R. (1999). Diagnostic and changing organizational culture. Based on the competitive values framework. Adison- Wesley, Boston. MA.

Cristian-Liviu, V. (2013). How culture and strategy interact. How does it works? An empirical Research. Analysis in the context of UAE Banking sector. International Journal of Economics and Finance, 22(1), 1690-1696.

Dadzie, C. A., Winston, E. M., \& Dadzie, K. Q. (2012). Organizational Culture, competitive advantage and performance in Ghana. Journal of African Business, 13(3), 172-182. https://doi.org/10.1080/15228916.2012.727737

Denison, D. R. (2000). Organizational culture: Can it be key lever for driving organizational change. In S. Cartwright \& C. Cooper (Eds.), The handbook of organizational culture. London: John Wiley \& Sons.

Denison. (1990). Corporate culture and organizational effectiveness. John Wiley \& Sons.

Dunn, K. (2012). “If It Ain't Cheap, It Ain't Punk": Walter Benjamin's progressive cultural production and DIY punk record labels. Journal of Popular Music Studies, 24(2), 217-237. https://doi.org/10.1111/j.1533-1598.2012.01326.x

Fazil, S., \& Alishahi, A. (2012). Investigating the relationship between organizational factors and performance through knowledge management. American Journal of Science and Research, 44(1), 116-1130.

Fiol, C. M. (1991). Managing culture as a competitive resource: An identity-based view of sustainable competitive advantage. Journal of Management, 17(1), $191-211$. https://doi.org/10.1177/014920639101700112

Grant, R. M. (1996). Towards a knowledge based theory of competitive advantage. Strategic Management Journal, 17(2), 109-122. https://doi.org/10.1002/smj.4250171110

Grant, R. M. (2003). Strategic planning in a turbulent environment: Evidence from the oil majors. Strategic Management Journal, 24(5), 491-517. https://doi.org/10.1002/smj.314

Gupta, B. (2011). A comparative study of organizational strategy and culture across industry: Benchmarking. An International Journal, 18(4), 510-528. https://doi.org/10.1108/14635771111147614

Hamel, G., \& Prahalad, C. K. (1990). The core competence of the corporation. Harvard Business Review, 71(3), 79-91.

Hofstede, G. H., Hofstede, G. J., \& Minkov, M. (2010). Cultures and organizations: Software of the mind. New York: McGrew-Hill.

Hofstede, G., \& Hofstede, G. J. (2005). Culture and organizations: Software of the mind. New York: McGrew-Hill.

Jochisen, B., \& Naipier, N. K. (2013). Organizational culture and competitive advantage: What next? Strategic Management, 2, 233-254.

Johannesson, J., \& Palona, I. (2010). The dynamic strategic capability. International Business Research, 3(1), 3-12.

Johnson, G., \& Scholes, K. (2005). Exploring corporate strategy (6th ed.). India: Pearson Prentice-Hall.

Kariuki, P. M. (2017). The relationship of organization culture and return on assets of large manufacturing companies in Kenya. International Journal of Science and Research Publications, 7(3), 495-498.

Kenya Association of Manufacturers (KAM). (2016). The Kenya association of manufacturers and exporters directory. Nairobi. Adafric Communications Limited.

KIPPRA. (2014). Kenya economic report 2014.Creating an enabling environment for stimulating investment for competitive and sustainable counties.

Kuhn, R., \& Grunig, R. (2000). Fundamentals of strategic planning: A comprehensive approach to evaluating strategies. Bern Switzerland: Haupt. 
Lopez, S. P., Peon, J. M. M., \& Ordas, C. J. V. (2004). Managing Knowledge: The link between culture and organizational learning. Journal of Knowledge Management, 8(6), 93-104. https://doi.org/10.1108/13673270410567657

Lund, D. B. (2003). Organizational culture and job satisfaction. Journal of Business and Industrial Marketing, 18(3), 219-236. https://doi.org/10.1108/0885862031047313

Mahoney, F. T., \& Pandian, J. R. (1992). The resource-based view within the conversation of strategic management. Strategic management Journal, 13(5), 363-380. https://doi.org/10.1002/smj.4250130505

Mehta, S., \& Krishnan, V. R. (2004). Impact of organizational culture and influence tactics on transformational leadership. Journal of Management and Labour Studies, 29(4), 281-290. https://doi.org/10.1177/0258042X0402900403

Murgor, P. K. (2014). External environment, firm capabilities, strategic response and performance of large manufacturing firms in Kenya. (Unpublished Ph.D. Thesis). University of Nairobi, Nairobi.

Navdeep, K. G. (2010). Innovation culture for sustainable competitive advantage. Sri Krishna International Research \& Educational Consortium APJRBM, 1(2), 2229-4104.

Nguyen, L. D., Mujtaba, B. G., \& Pham, L. N. T. (2013). Cross Culture Management: An examination on task, relationship and stress orientations of Japanese and Vietnamese. International Journal of Strategic Change Management, 5(1), 72-92. https://doi.org/10.1504/IJSCM.2013.057557

Norton, D. P. (1998). Management action and resource advantage theory: Conceptual framework emanating from a positive theory of competition. Journal of Business and Industrial Marketing, 27(7), 582-591.

Oke, A. (2007). Innovation types and innovation management in service companies. International Journal of Operations and Production Management, (27), 564-587. https://doi.org/10.1108/01443570710750268

Parnell, J. A., Long, Z., \& Lester, D. (2015). Competitive strategy, capabilities and uncertainty in small and medium enterprises (SMEs) in China and the United States. Management Decisions, 53(2), 402-431. https://doi.org/10.1108/MD-04-2014-0222

Pearce II, J. A., Robinson, R. B., \& Mital, A. (2012). Strategic Management: Formulation, implementation and control (12th ed.). New Delhi: Tata McGraw Hill Education Private Ltd.

Penrose, E. G. (1959). The theory of the growth of the firm. New York: Wiley.

Porter, M. E. (2008). The five competitive forces that shape strategy. Harvard Business Review.

Prajogo, D. I., \& Sohal. (2001).The relationship between total quality management practises and organizational culture. International Journal of operations \& Production Management, 25(11), 1101-1122. https://doi.org/10.1108/01443570510626916

Pruzen, P. (2001). Firm reputation: Image and identity. Copenhagen Business School. Firm Reputation Review, 4, 50-64. https://doi.org/10.1057/palgrave.crr.1540132

Ray, G., Barney, J. B., \& Muhanna, W. A. (2004). Capabilities, business processes and competitive advantage: Choosing the dependent variable in empirical tests of resource-based view. Strategic Management Journal, 25(1), 23-37. https://doi.org/10.1002/smj.366

Reichers, A. E., \& Schneider, B. (1990). Climate and culture: An evolution of constructs. Organizational Climate and Culture, 1, 5-39.

Rothaermel, F. T. (2008). Generating economic results. Advances in the study of entrepreneurship, innovation and economic growth.

Sachein, E. H. (1995). Organizational culture and leadership. San Francisco.CA. Jossey-Bass Publishers.

Siew K. J., \& Kelvin, Y. (2004). Firm culture and firm performance. Journal of Managerial Psychology, 19, 340-359.

Tsai, Y. (2011). Relationship between organizational culture, leadership behavior and job satisfaction. BMC Health Services Research, 11(98), 1-9. https://doi.org/10.1186/1472-6963-11-98

Wernerfelt, B. (1984). A Resource-based view of the firm. Strategic Management Journal, 5(2), 17-180. https://doi.org/10.1002/smj.4250050207

Yesil, S., \& Keya, A. (2013). The effect of organizational culture on firm financial performance: Evidence from a developing country. Procedia Social and Behavioural Sciences, 81, 428-437. 
https://doi.org/10.1016/j.sbspro.2013.06.455

Zollo, M., \& Winters, S. G. (2002). Deliberate learning and evaluation of dynamic capabilities. Organizational Science, 13, 339-351. https://doi.org/10.1287/orsc.13.3.339.2780

\section{Copyrights}

Copyright for this article is retained by the author(s), with first publication rights granted to the journal.

This is an open-access article distributed under the terms and conditions of the Creative Commons Attribution license (http://creativecommons.org/licenses/by/4.0/). 